Public Philosophy \& Democratic Education

Volume 5 • 2016 • Issue 2 • pp. 103-116 • DOI: 10.14746/fped.2016.5.2.14

Participatory Methods for Information Society Www. filozofiapubliczna.amu.edu.pl • ISSN 2299-1875

들 Creative Commons BY-NC-ND 4.0

\title{
The use of Geographic Information Systems in the participatory management of a big city. Case study of Gdynia
}

\section{Patrycia Grrys}

Abstruct:This paper examines the way of including society in decisionmaking processes within cities in the context of the ICT sector development and the usage of Geographical Information Systems (GIS). With universal access to information and increased possibilities of expression and gathering society's opinion, it creates new forms of democracy that are conducive to participatory management especially in urban units. One of the tools used by the municipal government for the realization of the idea of participation is the Public Participatory GIS (PPGIS).

In the first section of the text author focuses on the theoretical framework of social participation processes. Both on the processes of socio-economic transformation as well as on the legal conditions for participation in Poland. Afterwards, the author explains the idea of PPGIS and possibilities of its use in cities.

Next section applies to a case study of Gdynia referring earlier theoretical considerations to specific urban practice. There has been described geosurveys technique that was carried out in the city. The text outlines the way of its implementation and its results in the context of the decision and policy-making processes in the big cities on the example of Gdynia. These considerations fit into the theme of creating the information society in the

\footnotetext{
* University of Gdańsk (Poland) patrycja.grzys@phdstud.ug.edu.pl
} 
processes of city management, using participatory methods of Geographical Information Systems.

Keywords: Public Participation Geographical Information Systems (PPGIS), city management, information society, spatial planning, geosurveys, Gdynia

The development of information and communication technologies (ICT) is one of the basic elements of the contemporary transformations related to human environment. This progress is associated with the end of the industrial age and thereby with the transition from industrial to the post-industrial era, for whom no longer the industry, but the information and its management constitutes the basis of functioning (Reza, 1996). In this context, as it is presented in table 1, it is information, that creates a new type of capital whose main purpose is to ensure the harmonious development and general satisfaction. The tools and the organization of the new product have been adapted to the current processes of the globalizing economy, and not elements are those who play a predominant role, but networks and connections. Castells (1996) estimates the beginnings of the Revolution of Information Technology on the 70s of the twentieth century. It should be emphasized that the transition from the industrial age to the post-industrial, which Toffler (1980) calls the "third wave of change", is still at the initial stage of development, so the effects of these changes are noticeable only in the most developed parts of the world. The fact of using information, its processing or transferring is not a new phenomenon, however, the progress of globalization processes and the impact of technological development result in the circumstance that information, as such, has never played such a huge significance in human life.

The development of the ICT sector, which is one of the main sources of transformation of modern civilization, encompasses a very wide range of influences. It includes the impact on economic development (both in local and global scale) as well as on the social change: the daily life of the individual urban citizens and behavior patterns. Those changes are strictly connected with far wider possibilities. A society, where information and knowledge are 
Table 1: The comparison of transformations and changing conditions in the three modes of development (Reza, 1996, p. 13)

\begin{tabular}{|l|c|c|c|}
\hline & \multicolumn{3}{|c|}{ Modes of Development } \\
\cline { 2 - 4 } & Agricultural & Industrial & Informational \\
\hline $\begin{array}{l}\text { Dominant } \\
\text { tool }\end{array}$ & Plough & Machine & Computer \\
\hline Production & Food & Goods & Information \\
\hline $\begin{array}{l}\text { Strategic } \\
\text { resource }\end{array}$ & Land & Capital & Knowledge \\
\hline $\begin{array}{l}\text { Organiza- } \\
\text { tion of pro- } \\
\text { duction }\end{array}$ & Family & Company & Networks \\
\hline $\begin{array}{l}\text { Production } \\
\text { form }\end{array}$ & Self & Mass & Individual \\
\hline $\begin{array}{l}\text { Primary } \\
\text { work-force }\end{array}$ & Peasant & Proletariat & $\begin{array}{c}\text { Informational } \\
\text { Worker }\end{array}$ \\
\hline $\begin{array}{l}\text { Overall goal } \\
\text { Rurvival }\end{array}$ & $\begin{array}{c}\text { Material wel- } \\
\text { durables }\end{array}$ & $\begin{array}{c}\text { Mental well- } \\
\text { being, Flexible } \\
\text { sustainability }\end{array}$ \\
\hline Risk factor & Natural & Industrial & Informational \\
\hline $\begin{array}{l}\text { Spatial } \\
\text { transfor- } \\
\text { mation }\end{array}$ & Village/Town & $\begin{array}{c}\text { City/Megalop- } \\
\text { olis }\end{array}$ & $\begin{array}{c}\text { Multinodal } \\
\text { settlements/ } \\
\text { Telecottage/ } \\
\text { Computopolis }\end{array}$ \\
\hline $\begin{array}{l}\text { Pace } \\
\text { of change }\end{array}$ & Slow & Rapid & Super rapid \\
\hline
\end{tabular}

the primary factors of production, is defined by Japanese authors and propagators of this concept Umesao (1963) and Koyama (1968) as the information society. According to the assumptions of Mączyński (1997) information society has the skills of production, storage, processing and transmission of information in today's conditions. It has two other properties which are the collection and use of information that are particularly relevant in the context of this paper, as they assume ability to collect information from all interested and then use them in a way that is designed to bring potential benefits for those who are involved.

A valuable feature of information is fact that it is selfreinforcing and reusable. Once used information does not lose its value, it is even increasing it. Thus, the processing 
of information by the society is the process by which a very large amount of resource in the form of knowledge can be obtained. The essence of the information society is therefore not bringing individual to the role of passive recipient, but the ability to use gained knowledge appropriately as an opportunity to influence the content of the gained information.

With the widening access to information by citizens and increasing possibilities to express opinions, society creates new forms of democracy that are conducive to participatory management especially in urban units (Kliksberg, 2001). Cities constitute contemporary centers of modern technologies. The way by which the resource of knowledge is processed often indicates if the city is innovative or not and therefore if it is competitive on the global market. The purpose of the city is thus supporting its citizens, helping them to organize and participate in social circulation of information in accordance with the principle that the city is the common good of all its citizens (Foster, 2015).

\section{Legal conditions of social participation in Poland}

Full exploit of the democratic potential of the new information and communication technologies requires not only the ability of society but also guarantee of the right to access the information, in particular this created and stored by the public administration. The legislature in Poland provides a legal basis for public access to information both by the highest legal act which is the Constitution of the Republic of Poland ${ }^{1}$ and by other laws. This paper will be limited to the scale of the city and local management and, in particular, to aspects of spatial planning.

Polish legislature admittedly determines on what conditions and in what circumstances the information can and should be transmitted to the public, however, it does not specify exactly its form. Consequently, realizing the obligations, municipalities are only required to communicate information, without encouraging citizens to participate in their managing what can be done on several levels.

1 The Constitution of the Republic of Poland of $2^{\text {nd }}$ April 1997. Published in Journal of Laws No. 78, item 483. 
As an example, IAP2 Spectrum of Public Participation model (IAP2, 2007) provides that citizens can participate in the public space as actors (1) receiving information, (2) consulting projects, actions and decisions, (3) identifying and communicating problems and social needs, (4) defining decision problems, their premises and alternative solutions and (5) taking direct part in decision-making processes. Czepkiewicz (2013, p. 113) presents how geographic information systems can be used while including citizens in public processes at each of the levels indicated by the IAP2.

The above described conditions predominantly cause the fact that at the present time in a large number of small cities the first level of participation, which is limited to informing, is still dominant. These municipalities fulfill the legal obligation, although they are only at the initial stage of the implementation of the information society concept with all its consequences. They are limited only to the transfer of knowledge, and consultations with citizens, if any, are purely informative. Next level of participation assumes receiving feedback, so in addition to the transmission of information, it is also collected. However, it is still an indirect way of cooperation. Only the third level of participation determined by Czepkiewicz (2013) takes into account the direct nature of participation and besides transferring and retrieving information it also assumes its production. The next two levels of participation are still rare in Polish cities. They are based on established partnerships with the society recognizing their decisions as equal and even at the last stage allowing them to make the final decision.

The level of participation and actual cooperation that will be implemented in the municipality depends largely on the decision of local authorities. Some of the cities in Poland do use the possibilities of shaping local law introducing excessive forms and techniques of social participation, in order to adjust local policy to the real needs of their citizens. Recognizing the participatory management principle of the city authorities practice different methods of cooperation. They often include in this process experts in terms of working with local communities and IT specialists when they use GIS methods while working with them. Some of these methods are listed in table 2. One of them, which is geosurvey, will be further described in the following part of the case study. 
Table 2: Spectrum of public participation including example usage of the Internet and Geographic Information Systems (adapted from: Czepkiewicz, 2013, p. 113)

\begin{tabular}{|c|c|c|}
\hline \multicolumn{2}{|c|}{$\begin{array}{c}\text { IAP2, } 2007 \text { (Spectrum } \\
\text { of Public Participation) }\end{array}$} & \multirow{2}{*}{$\begin{array}{c}\text { Czepkiewicz, } 2013 \\
\text { Example of GIS } \\
\text { and online tools }\end{array}$} \\
\hline $\begin{array}{l}\text { Level } \\
\text { of public } \\
\text { impact }\end{array}$ & Goal & \\
\hline Inform & $\begin{array}{l}\text { To provide the public } \\
\text { with balances and objec- } \\
\text { tive information to assist } \\
\text { them in understanding } \\
\text { the problem, alternatives, } \\
\text { opportunities, and/or solu- } \\
\text { tions. }\end{array}$ & $\begin{array}{l}\text { Newsletter on the plan- } \\
\text { ning works in progress. } \\
\text { Maps posted on the inter- } \\
\text { net with the effects of the } \\
\text { proposed changes on the } \\
\text { natural environment. }\end{array}$ \\
\hline Consult & $\begin{array}{l}\text { To obtain public feedback } \\
\text { on analyses, alternatives } \\
\text { and/or decisions. }\end{array}$ & $\begin{array}{l}\text { Use a geosurvey to assess } \\
\text { the current and preferred } \\
\text { resident activities. Collect } \\
\text { requests and remarks con- } \\
\text { cerning the local spatial } \\
\text { management plan availa- } \\
\text { ble on the internet in the } \\
\text { form of comments. }\end{array}$ \\
\hline Involve & $\begin{array}{l}\text { To work directly with pub- } \\
\text { lic throughout the process } \\
\text { to ensure public concerns } \\
\text { and aspirations are con- } \\
\text { sistently understood and } \\
\text { considered. }\end{array}$ & $\begin{array}{l}\text { Internet discussion on } \\
\text { the proposed solutions } \\
\text { with designers and par- } \\
\text { ticipants actively sought } \\
\text { through social media. }\end{array}$ \\
\hline $\begin{array}{l}\text { Collabo- } \\
\text { rate }\end{array}$ & $\begin{array}{l}\text { To partner with the public } \\
\text { in each aspect of decision, } \\
\text { including the development } \\
\text { of alternatives and the } \\
\text { identification of the pre- } \\
\text { ferred solution. }\end{array}$ & $\begin{array}{l}\text { Social representatives } \\
\text { determine the criteria and } \\
\text { weights used to assess the } \\
\text { proposed solutions. The } \\
\text { entries of the local spa- } \\
\text { tial management plan } \\
\text { are drafted with planning } \\
\text { designers and residents. } \\
\text { Electronic voting on the } \\
\text { proposed solutions ending } \\
\text { in recommendations sub- } \\
\text { mitted to decision makers. }\end{array}$ \\
\hline Empower & $\begin{array}{l}\text { To place final decision } \\
\text { making in the hands } \\
\text { of the public. }\end{array}$ & $\begin{array}{l}\text { Legally binding electronic } \\
\text { voting on the implementa- } \\
\text { tion of the solution. }\end{array}$ \\
\hline
\end{tabular}




\section{Public Participatory Geographicic Information Systems in city mannagement}

There is still lack of agreement about the term Public Participatory Geographic Information Systems (Ramasubramanian, 2010). For the purpose of this paper its author stands for the statement that Public Participatory Geographical Information Systems in the context outlined above constitute a tool that is predestined to help local community to be actively involved in decision making processes and at the same time helps municipalities adopt participatory management approach. The idea of PPGIS was born in the late 90s of the twentieth century (Schuurman, 2004). The main environment for PPGIS is of course the Internet. It allows not only systematic collection of data from citizens and providing them to the appropriate units of the city, but also for all kinds of public participation in shaping the policy of the city - from basic elements such as reporting ideas or problems to the co-decision processes. Such system usually does not require the user to install any kind of software, which makes it simpler and more user-friendly for most people, who have even minimal computer skills. The data which are most often presented by this tool are demographic data for the general public, or data related to planned investments, because these are the elements that should be given for public consultation. The primary objective of PPGIS is therefore to bring the academic practices of GIS and mapping to the local level in order to promote knowledge production by local and non-governmental groups interested in supporting their causes (Schuurman, 2004).

PPGIS therefore contributes to the way of using the latest technology to enable a bottom-up collection of data from the individual components of the city, reporting problems in urban areas, as well as carrying out a social diagnosis of the quality of the space and promoting public participation in decision-making processes. Benefits of using such a system to manage the city are not limited only to one side of the process, as shown in table 3. The use of PPGIS can bring beneficial effects for each of the potential users. One of the most important benefit, which also formed the basis of the creation of this tool, is forming better solutions to the needs of local communities through appropriate recognition 
of these needs. Properly conducted public participation can prevent numerous space conflicts (Pawłowska, 2010). Avoiding conflicts or averting them at an early stage accelerates the processes of planning and investment. Well-informed and confident about taking into account their voice stakeholders will have less tendency to oppose against the developed solutions. Thus the community gets an increased opportunity to participate in decision-making processes within the place of living. This possibility is adjusted to their skills and capabilities. The local authority is gaining increased reliance, as well as the convenience of proper identification of needs, what used in the right way can have an impact on the creation of a positive image of the city in general. Experts, on the other hand, are gaining a very functional tool which simplifies analyzing and interpreting collected data. Consequently, as it was already mentioned, it accelerates the process of making and issuing decisions, what in the far-reaching effects may contribute to the acceleration of investment processes in the city.

Table 3: Benefits and limitations of implementing PPGIS in city management

\begin{tabular}{|c|c|}
\hline Benefits & Limitations \\
\hline $\begin{array}{l}\text { - help in building social capital } \\
\text { - increased confidence in public } \\
\text { administration } \\
\text { - stronger attachment to the } \\
\text { place } \\
\text { - increased ability to visualize } \\
\text { presented data } \\
\text { - ease of analysis and interpre- } \\
\text { tation of the acquired data } \\
\text { - proper recognition of social } \\
\text { needs } \\
\text { - increased availability of the } \\
\text { presented data } \\
\text { - conflict prevention } \\
\text { - cester decision-making pro- } \\
\text { - help in creating a positive } \\
\text { image of the city }\end{array}$ & $\begin{array}{l}\text { - exclusion of certain social } \\
\text { groups } \\
\text { - anonymity of Internet users } \\
\text { - dependence on the goodwill } \\
\text { of specialist and government } \\
\text { - low impact } \\
\text { - the high cost of obtaining data } \\
\text { to implement the system }\end{array}$ \\
\hline
\end{tabular}


However, despite the attempts to maximize the advantageous impact of PPGIS there are still some limitations of its functioning. Most of them depend on the human factor, so it can be assumed that with the development of the information society skills and with the increasing role of participation in the management of cities, these limitations can be minimized. One of the primary obstacles is marginalization of certain social groups. Despite the fact that one of the objectives of PPGIS is the prevention of marginalization, the lack of basic computer skills effectively prevents the independent use of the methods proposed by PPGIS. The anonymity of the Internet makes it difficult to determine the recipient of the data and its real intentions that may affect the appropriate image of data obtained from the public. An appropriate level of social influence on the ultimate decision-making policy still remains an important issue, which is closely dependent on the authorities. Nevertheless, the positive aspect is the fact that when the municipalities decide to undertake the PPGIS techniques in city management, they treat the results obtained in the framework of that system seriously and, if possible, actually use them.

\section{The case study of Gdynio}

One of the Polish cities, which has a policy of co-management, is Gdynia. It is a municipality belonging to the Gdansk-Gdynia-Sopot Metropolitan Area, commonly called the Tri-City. It is a city with a population exceeding 247 thousand $^{2}$ and is classified, within the Polish conditions, as a big city (Runge, 2012). Gdynia is a city that has long been implementing the idea of participation in policy development. Already in the Study of Conditions and Directions of Spatial Management from 2008 there is a notice that refers to the principle of participation, which should be broad and active ${ }^{3}$. Municipality performs this obligation at

1 Central Statistical Office of Poland, as of $30^{\text {th }}$ of June 2016.

3 Study of Conditions and Directions of Spatial Management of the City of Gdynia approved by resolution no. XVII/400/08 Gdynia City Council of $27^{\text {th }}$ of February 2008. 
many levels of participation using methods of consultation with the public. The author of this work decided to describe one of the methods of cooperation with the public which are geosurveys.

Geosurvey is a method of social participation used mainly in environmental management or spatial planning. It depends mostly on the social diagnosis of a specific part of space or a problem that occurs in it. Data are collected from residents and users of space with the help of geographical online surveys - questionnaires combined with spatial information. Maps, plans and drawings can play the role of a background on which the user is asked to select specific areas or points, but they may also be only a reference to questions not directly related to any specific location. This method comes from Finland. Kahila and Kytta (2010), the Finnish duo, are considered to be authors of geosurvey method. Thanks to the fact that data are collected in a digital form, they can be easily incorporated into far broader overall urban geographic information systems.

In the case of the city of Gdynia, the aim was to use geosurveys to obtain opinions on advertisements in the city. As it can be read in the introduction to the survey it was created in reference to the entry into force of the act from 24 April 2015 "On amending certain laws in connection with the strengthening of the tools of landscape conservation", commonly called the "Landscape Act." "Through this law municipalities were given the opportunity to define "Terms and conditions of locating objects of small architecture, billboards, advertising equipment and fencing" for their administrative areas. The geosurvey conducted in Gdynia lasted 13 days from the 5th to the 18th of April 2016.

It was decided to carry out this particular method in order to receive larger number of opinions in the context of determining the shape of the new resolution. City of Gdynia commissioned the development of the platform with the survey to an external enterprise - StructView

4 The Act of $24^{\text {th }}$ April 2015. On amending certain laws in connection with the strengthening of the tools of landscape conservation. Published in Journal of Laws, item 774. 
FRAME for City. It is worth noting that geosurvey was used at the initial stage of the project, so that all the voices of all relevant stakeholders could have been taken into account in the decision-making process. The city decided to use the geosurvey method instead of conventional public consultations due to the fact that the topic related to the aesthetics of the urban space in conjunction with its legal conditions is highly complex and controversial. What is more, it was considered that the visual support would encourage more people to participate in the expression of their opinions than it would have taken place during the form of the usual public consultation.

The survey available through the Internet platform included a three-dimensional model of the city, on which there were links to specific questions related to a specific location, as shown in figure 1 and 2.

Users were not forced to answer all the questions. They were able to choose ones that are associated with their immediate surroundings. Apart from the questions directly linked to the location of the model the survey was supplemented with general questions about the aesthetics of adverts located in the city. At the end of the survey questions related to respondents' age and gender were asked.

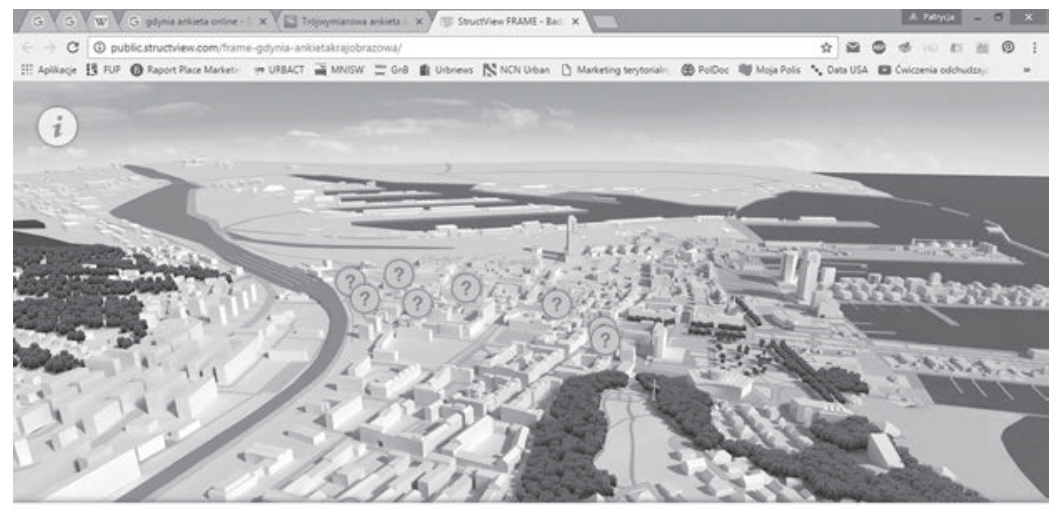

Klikaj kolejno na znaczniki i odpowiadaj na pytania.

$<$ Poprzednie

Następne >

[ [3:

Figure 1. The view of the main page of the survey. The command reads: "Click successively on the markers and answer questions." 


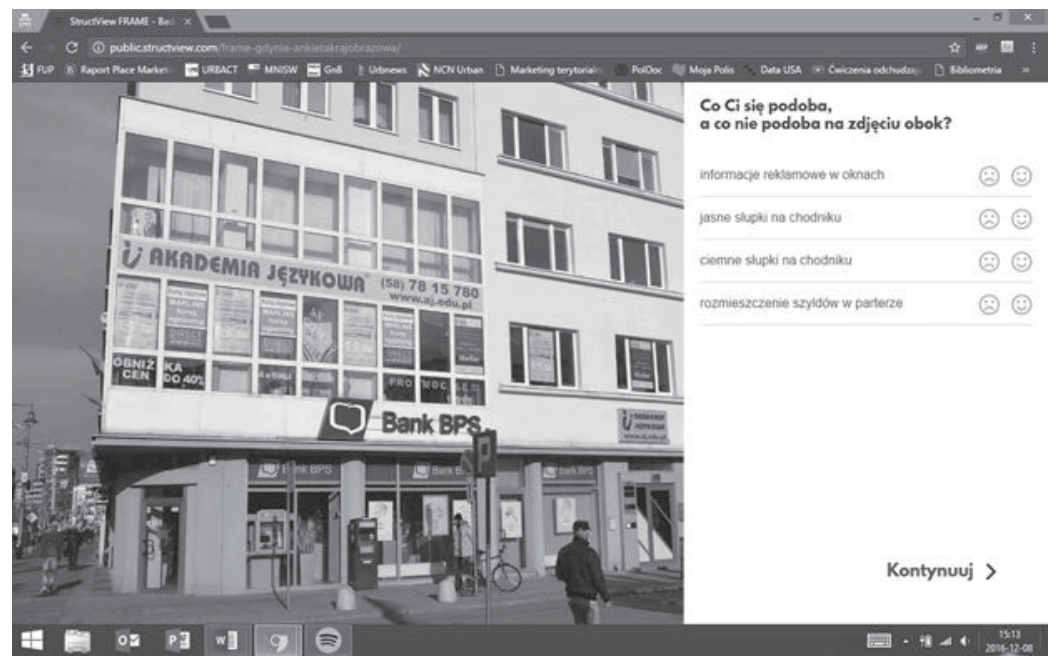

Figure 2. The view of the particular problem areas addressed in the survey. The question reads: "What do You like and what don't You like in the picture: adverts in windows/light pillars on the sidewalk/dark pillars on the sidewalk/placements of signs on the ground floor."

As it can be observed in the figures above, the questionnaire's interface proposed by StructView FRAME for City is very simple and user friendly. All the necessary information both in relation to the circumstances of the survey carried out and on how to navigate through the website were presented at the beginning. The aim of the project, as already mentioned, was to obtain an opinion on the advertisements in the city. The goal has been successfully achieved through the process of social dialogue with the use of innovative tools - geographical surveys (geosurveys) based on the PPGIS technique. The large amount of information that was gathered enabled the municipality to focus on the actual problem areas and specific problems. This subsequently allowed for further prioritization of tasks.

\section{Conclusion}

The use of a tool which is PPGIS in city management constitutes, based on the above considerations, an important 
element in shaping the information society. The development of the idea of participation, which is not respected only by fulfilling the legal obligation imposed on the urban unit but actually involves citizens in decision and policy making processes, brings a number of benefits, which may allow the city to become a competitive entity in the international arena. Public involvement can take many forms, but the most effective are those that allow to collect the highest number of votes and opinions, what PPGIS has an aim to help with. The way in which PPGIS uses information as a fundamental resource of modern civilization is designed to provide maximum benefits for every stakeholder.

PPGIS can successfully be used in city management, especially in activities related to land use planning, green management, or general investment planning. It should be of course remembered that PPGIS may constitute only one element of the whole process of participation and its methods can be implemented at different stages of the process. Currently, methods of PPGIS are commonly used as part of the diagnosis and the study of social needs in the early stages of planning. To promote social participation in other stages of the decision-making processes other methods and tools are necessary.

The level of use of GIS tools in Poland is still at a medium level. The vast majority of large municipalities in Poland uses them in its management, although still a small part of them implements PPGIS. Nevertheless, the pace of ICT technology development in conjunction with the development of the information society makes the future of Geographic Information Systems in city management and planning in Poland promising.

One of the forms of such a system, which is geosurvey, has been described in the paper. However, it is not the only case of PPGIS implementation in Poland. Other projects using PPGIS methods are developed in Poland both in large cities like Poznan and in smaller ones like Rokietnica. Internet tools probably will not ever replace traditional methods of participation, however, they can supplement them through the inclusion of the society in information and knowledge management processes. 


\section{References}

Castells, M. (1996). The Rise of the Network Society: The Information Age: Economy, Society and Culture. Oxford: Blackwell Publishers.

Czepkiewicz, M. (2013). Geographic information systems in participatory management of nature in the city. Sustainable Development Applications, 4, 110-123.

Foster, S. (2015, October, 30). Cities, Inequality and the Common Good. Retrieved from Huffington Post: The World Post: http://www.huffingtonpost.com/sheila-foster/cities-inequality-and-the_b_8435316.html, accessed 15.12.2016.

IAP2 (2007). IAP2 Spectrum of Public Participation, Thornton, CO: International Association for Public Participation.

Kliksberg, B. (2001). Towards an Intelligent State. Amsterdam: IOS Press.

Koyama, K. (1968). Introduction to the Information Theory. Tokyo.

Mączyński, J. (1997). Globalne społeczeństwo informacyjne. Wybrane kwestie adaptacyjne. In: L. W. Zacher, Rewolucja informacyjna $i$ społeczeństwo. Niektóre trendy, zjawiska $i$ kontrowersje. Warszawa: Fundacja Edukacyjna "Transformacje".

Pawłowska, K. (2010). Zanim wybuchnie konflikt. Idea i metody partycypacji społecznej $w$ ochronie krajobrazu i ksztattowaniu przestrzeni. Kraków: Fundacja Partnerstwo dla Środowiska.

Ramasubramanian, L. (2010). Geographic Information Science and Public Participation. London: Springer.

Reza, K. (1996). Networking and placemaking. Nordic Journal of Architecture Research, 9(4), 7-22.

Runge, A. (2012). Methodological problems associated with research on midsize towns in Poland. Prace Geograficzne, 129, 83-101.

Schuurman, N. (2004). GIS. A short introduction. London: Wiley-Blackwell.

Toffler, A. (1980). The Third Wave: The Classic Study of Tommorow. New York: Bantam Books.

Umesao, T. (1963). Information Industry Theory: Dawn of the Coming Era of the Ectodermal Industry. Tokyo: Asahi Hoso. 